\title{
New edition of European regulations concerning axle boxes, rolling bearings and greases in the aspect of operational safety. Greases for rolling bearings
}

\section{Nowa edycja przepisów europejskich, dotyczących maźnic, lożysk tocznych oraz smarów w aspekcie bezpieczeństwa eksploatacyjnego. Smary do lożysk tocznych}

\begin{abstract}
The article presents the currently valid regulations concerning axle boxes, bearings and greases for running gear systems of rail vehicles in the aspect of operational safety, running in the domestic and cross-border traffic. The article deals with the significant problems regarding the approval process of individual components, i.e. bearing greases, bearings and axle boxes. The new European standards are an important guarantor of the comprehensive safety of wheelsets and running gear systems of railway vehicles. This article deals with rolling bearings greases used in the country.
\end{abstract}

W artykule przedstawiono aktualnie obowiqzujace przepisy dotyczqce maźnic, tożysk oraz smarów dla układów biegowych pojazdów szynowych $w$ aspekcie bezpieczeństwa eksploatacyjnego, kursujacym w ruchu krajowym oraz transgranicznym. Artykut porusza istotne problemy dotyczace procesu homologacji poszczególnych elementów tzn. smarów tożyskowych, tożysk oraz maźnic. Nowe normy europejskie sq istotnym gwarantem kompleksowego bezpieczeństwa zestawów kołowych oraz układów biegowych pojazdów szynowych. W tym artykule zajęto się smarami do tożysk tocznych, używanymi w kraju.

\section{INTRODUCTION}

The operational safety of rail vehicles is a constantly developing concept, due to the increasing requirements in railway transport. An important element of the new strategy of approval, adopted in the railway transport is providing the quality of vehicles, for which the producer of the rail vehicle is responsible [1]. Increasing requirements for rail transport are the result of market competition on the transport market both in the field of passenger as well as freight transport. The European Union Directives are certainly a facilitation for freight transport, according to which the railway infrastructure of the Member States is separated from the companies providing transport services. In this way, if the vehicle meets the requirements of the TSI (Technical Specifications for Interoperability), then the transport company can use the entire railway infrastructure of the European Union Member States and European countries not affiliated with it, respecting the rules of standards developed by the European Committee for Standardization and EU Directives. In this way, the transport capacity is increased, first of all in the scope of their range in both freight and passenger transport.

The final rail vehicle producer must provide the following features, which are then the criteria for the producer's assessment by the carrier:

\section{WSTĘP}

Bezpieczeństwo eksploatacyjne pojazdów szynowych jest pojęciem stale rozwijającym się, $\mathrm{z}$ uwagi na wzrastajace wymagania $\mathrm{w}$ transporcie kolejowym. Istotnym elementem nowej strategii, przyjętej $\mathrm{w}$ transporcie kolejowym, która zapewnienie jakości pojazdów powierza producentowi pojazdu szynowego [1]. Wzrastające wymagania dotyczące transportu szynowego są wynikiem, rywalizacji rynkowej na rynku przewozowym zarówno w zakresie transportu osobowego jak również ładunków. Ułatwieniem dla transportu towarowego są na pewno Dyrektywy Unii Europejskiej, w myśl których oddzielono infrastruktura kolejową państw członkowskich od firm świadczących usługi transportowe. W ten sposób, jeśli pojazd spełnia wymagania przepisy TSI (Warunki Techniczne Interoperacyjności), to wówczas przedsiębiorstwo przewozowe może korzystać z całej infrastruktury kolejowej państw członkowskich Unii Europejskiej oraz krajów europejskich $\mathrm{w}$ niej niezrzeszonych, respektujących przepisy norm opracowanych przez Europejski Komitet Normalizacyjny oraz Dyrektywy UE. W ten sposób zwiększa się możliwości przewozowe, przed wszystkim $\mathrm{w}$ zakresie ich zasięgu zarówno $\mathrm{w}$ transporcie towarowym i osobowym.

Producent finalny pojazdu szynowego musi zapewnić następujące cechy, które są potem kryteriami oceny producenta przez przewoźnika: 
$>$ reliability

$>$ availability

$>$ maintenance-free operation of individual subsystems and systems as well as subassemblies and assemblies of vehicle

$>$ high durability and service life of individual components

$>$ low emission of noise and harmful substances to the natural environment

$>$ fire resistance

$>$ relatively low own weight (ultra-light constructions)

$>$ low energy consumption and $\mathrm{CO}_{2}$ emission to the atmosphere

$>$ possibility of recovering braking energy to special storage

$>$ meeting the electromagnetic compatibility conditions in order to limit the negative impact on devices intended for controlling the railway traffic (srk)

$>$ adaptation to riding on the electrified and nonelectrified routes

$>$ adapting the electric drive system to multiple supply systems $1,5 \mathrm{kV}_{\mathrm{DC}}, 3 \mathrm{kV}_{\mathrm{DC}}, 25 \mathrm{kV}-50 \mathrm{~Hz}$ and $15 \mathrm{kV}-16,7 \mathrm{~Hz}$

$>$ adaptation of the vehicle to the use of braking energy for traction purposes and the use of fuel cells

$>$ possible limitations of the impact on track infrastructure in the sense of forces and accelerations

$>$ protection of the vehicle structure against the effects of collisions in accordance with PN-EN $15227+\mathrm{A} 1: 2011[6]$

$>$ equipment with diagnostic means, allowing to determine in advance the location of the rail vehicle on the route, the condition of the load, the temperature of the axle box bearings and the brake discs and to detect a possible threat of operational safety

$>$ optimal use of the kinematic gauge reference profile, which in turn guarantees the largest possible real outline of the vehicle, increasing the ride comfort and transport possibilities

$>$ compatibility of the stair with the height of the platform

$>$ modular structure construction, which in turn facilitates the process of production and modernization as well as vehicle repairs and maintenance

$>$ adaptation of the vehicle to the European traffic train control system ETCS (Level 1, Level 2 and Level 3).

Above mentioned requirements for rail vehicles, at the same time have an impact on the rational use of railway infrastructure.

This article discusses the problem of greases for axle box bearings used in the country in comparison with the requirements of the European standard PN-EN 12081: 2017 [4]. The designation of the grease, its
$>$ niezawodność

$>$ dyspozycyjność

$>$ bezobsługowość poszczególnych subsystemów i systemów oraz podzespołów oraz zespołów pojazdu

$>$ wysoką trwałość i żywotność poszczególnych części składowych

$>$ niską emisję hałasu i substancji szkodliwych do środowiska naturalnego

$>$ odporność na palność

$>$ relatywnie niską masę własną (ultralekkie konstrukcje)

$>$ niskie zużycie energii i emisja $\mathrm{CO}_{2}$ do atmosfery

$>$ możliwość odzyskiwania energii hamowania do specjalnych zasobników

$>$ spełnienie warunków kompatybilności elektromagnetycznej, w celu ograniczenia negatywnego oddziaływania na urządzenia przeznaczone do sterowania ruchem kolejowym (srk)

$>$ dostosowanie do jazdy po trasach zelektryfikowanych oraz niezelektryfikowanych

$>$ dostosowanie elektrycznego systemu napędowego do wielu systemów napięcia zasilania $1,5 \mathrm{kV}_{\mathrm{DC}}, 3$ $\mathrm{kV}_{\mathrm{DC}}, 25 \mathrm{kV}-50 \mathrm{~Hz}$ oraz $15 \mathrm{kV}-16,7 \mathrm{~Hz}$

$>$ dostosowanie pojazdu do wykorzystania energii hamowania w celach trakcyjnych oraz korzystania $\mathrm{z}$ ogniw paliwowych

$>$ możliwe ograniczenia oddziaływania na infrastrukturę torową w sensie sił i przyspieszeń

$>$ zabezpieczenie konstrukcji pojazdu przed skutkami zderzeń zgodnie z PN-EN 15227+A1:2011[6]

$>$ wyposażenie w środki diagnostyczne, pozwalające w porę określić lokalizację pojazdu szynowego na trasie, stan ładunku, temperaturę łożysk maźniczych i tarcz hamulcowych i wykryć ewentualne zagrożenie bezpieczeństwa eksploatacyjnego

$>$ optymalne wykorzystanie zarysu odniesienia skrajni kinematycznej, co gwarantuje z kolei możliwie największy rzeczywisty zarys pojazdu, zwiększający komfort jazdy i możliwości przewozowe

$>$ kompatybilność stopnia wejściowego z wysokością peronu

$>$ modułową budowę konstrukcji, co z kolei ułatwia proces wytwarzania i modernizacji oraz napraw i konserwacji pojazdu

$>$ przystosowanie pojazdu do europejskiego systemu zabezpieczenia ruchu pociagów ETCS (Level 1, Level 2 oraz Level 3).

Wyżej wymienione wymagania dotyczące pojazdów szynowych maja jednocześnie wpływ na racjonalne wykorzystanie infrastruktury kolejowej.

W niniejszym artykule poruszono problem smarów do łożysk maźniczych, stosowanych w kraju w porównaniu $\mathrm{z}$ wymaganiami normy europejskiej PN-EN 12081:2017[4]. Oznaczenie smaru, jego ilość która powinna znaleźć się w korpusie maźnicy, wynika z 
quantity that should be in the axle box body, results from the constructional documentation of the given node (in this case the axle box).

2. Greases used for rolling bearings, mounted in axle box

2.1. Greases used for railway bearings in the country

In the national railway market, LT41 greases with consistency class $1, \mathbf{L T} \mathbf{4 2}$ with consistency class 2 and LT43 consistency class 3 are still used. The grease is defined as "a product with a consistency from liquid to solid obtained from a thickener (gelling substance) in base oil, creating a chemically homogeneous preparation ("three-dimensional cross-linking colloidal system"). The following definition is given in PN-72/C-96134 [10]: "plastic grease $t T$ of general application for rolling bearings is obtained by concentrating refined mineral oils with soaps with the addition of inhibitors". However, the different definition is already included in PN-EN 12081: 2017 standard [4]: "Semi-solid grease, which consists of a thickener and additives dissolved in lubricating oil." Both definitions are correct, however, limiting to explaining the composition of the grease as a substance. They should be supplemented with a different definition which has a different meaning, and which sounds as follows:

"Grease is a structural element that thanks to its properties ensures the functioning of the bearing (bearing set) built in the axle box body with the definite shape in normal and extreme operating conditions, guaranteeing it the correct operation and service life assumed by the designer".

As mentioned earlier, the name of the grease, the reference standard, the type of bearings, the way of build in (structure of the axle box body), the type of used seal and the quantity, that should be used, results from the constructional documentation and the Technical Conditions of Performance and Acceptance of the vehicle's running gear system. This definition does not question the previous two ones, but more it gives the sense of using a grease without which the bearing cannot function. From this definition, it can be concluded that the use of a bearing without the associated grease (s) does not make any sense. As it results from industrial practice, ŁT43 grease is still used and the properties correspond to those listed in the PN-72/C96134 standard [10]. In addition the situation is complicated by the fact that the PN-72/ C-96134 standard [10] was annulled or withdrawn on 15 February 2006. by the Polish Committee for Standardization. The use of this grease nowadays is supported by many years of operational practice on PKP lines.

Properties of ŁT41, ŁT-42 and ŁT-43 greases are presented in the table1. dokumentacji konstrukcyjnej danego węzła (w tym przypadku maźnicy).

\section{Smary stosowane do lożysk tocznych, zamonto- wanych w maźnicy}

\subsection{Smary stosowane do łożysk kolejowych w kra-} ju

W krajowym rynku kolejowym nadal są stosowane smary LT41 o klasie konsystencji 1, LT 42 o klasie konsystencji 2 oraz $\mathbf{L T 4 3}$ o klasie konsystencji 3. Smar definiuje się „jako produkt o konsystencji od płynnej do stałej otrzymanej z zagęszczacza (substancji żelujacej) w oleju bazowym, tworzqc preparat jednolity chemicznie (,,usieciowanie trójwymiarowesystem koloidalny"). W normie PN-72/C-96134 [10] jest podana następująca definicja: „smar plastyczny $Ł T$ ogólnego stosowania do tożysk tocznych otrzymuje się przez zagęszczanie rafinowanych olejów mineralnych mydlami z dodatkiem inhibitorów". Natomiast w normie PN-EN 12081:2017 [4] jest zamieszczona już inna następująca definicja: ,pótstała substancja smarujaca, która składa sie z zagęszczacza $i$ dodatków rozpuszczonych w oleju smarnym." Obie definicje sa słuszne, jednak ograniczają się do wyjaśnienia składu smaru jako substancji. Powinny być uzupełnione o inną definicję, która ma już inne znaczenie, a która brzmi następująco:

„Smar jest elementem konstrukcyjnym, który dzięki swoim własnościom zapewnia funkcjonowanie tożyska (zespotu tożyskowego) zabudowanego $w$ korpusach maźniczych o określonym kształcie w normalnych oraz ekstremalnych warunkach eksploatacyjnych, gwarantujac prawidlowe działanie oraz żywotność, zalożone przez projektanta".

Jak już wcześniej wspomniano nazwa smaru, norma odniesienia, typ łożysk, sposób zabudowy (konstrukcja korpusu maźnicy), typ zastosowanego uszczelnienia oraz ilość, którą należy zastosować, wynika z dokumentacji konstrukcyjnej oraz z Warunków Technicznych Wykonania i Odbioru układu biegowego pojazdu. Ta definicja nie kwestionuje dwóch poprzednich, ale bardziej oddaje sens zastosowania smaru, bez którego łożysko nie może funkcjonować. Z tej definicji można wyciagnąć wniosek, że zastosowanie łożyska bez związanego z nim smaru (smarów) nie ma żadnego sensu. $Z$ takiej definicji wynika, że smar jest środkiem związanym z łożyskiem, którego istnienie samo w sobie nie ma sensu. Jak wynika z praktyki przemysłowej smar ŁT43 jest wciąż stosowany, a własności odpowiadają tym, które są wymienione w normie PN-72/C-96134 [10]. Sytuację komplikuje dodatkowo fakt, że norma PN-72/C-96134 [10] jest unieważniona lub wycofana w dniu 15.02 .2006 przez Polski Komitet Normalizacyjny. Za stosowaniem tego smaru dzisiejszych czasach przemawia długoletnia praktyka eksploatacyjna na liniach PKP. Własności smarów ŁT41, ŁT-42 oraz ŁT-43 są przedstawione $\mathrm{w}$ tablicy1. 
Properties of bearing LT41, ŁT-42 and LT-43 greases according to PN-72/C-96134 [10] Table 1 Wlasności smarów lożysk ŁT41, ŁT-42 oraz LT-43 wg PN-72/C-96134 [10]

Tablica 1

\begin{tabular}{|c|c|c|c|c|c|}
\hline $\begin{array}{l}\text { Lp./ } \\
\text { Item }\end{array}$ & $\begin{array}{c}\text { Własności smarów dla lożysk, zamontowanych w korpusie } \\
\text { maźnicy/ Properties of greases for bearings mounted in } \\
\text { the axle box body }\end{array}$ & LT-41 & LT-42 & LT-43 & $\begin{array}{l}\text { Metoda badań wg/ } \\
\text { Method of tests } \\
\text { according to }\end{array}$ \\
\hline 1. & $\begin{array}{l}\text { Penetracja w temperaturze } 25^{\circ} \mathrm{C} \text { po ugniataniu/ Worked } \\
\text { penetration at } 25^{\circ} \mathrm{C} \text { after kneading }\end{array}$ & $305 \div 345$ & $260 \div 300$ & $215 \div 255$ & $\mathrm{PN}-71 / \mathrm{C}-04135[9]$ \\
\hline 2. & $\begin{array}{c}\text { Temperatura kroplenia }{ }^{\circ} \mathrm{C} \text { nie niższa niż/ Dropping point }{ }^{\circ} \mathrm{C} \\
\text { not lower than }\end{array}$ & 170 & 175 & 180 & $\mathrm{PN}-55 / \mathrm{C}-04020[11]$ \\
\hline 3. & $\begin{array}{l}\text { Badanie działania korodującego na płytkach z miedzi w } \\
\text { temperaturze } 100^{\circ} \mathrm{C} w \text { ciagu } 3 \text { godzin/ Test of the corrosive } \\
\text { action on the copper plates at } 100^{\circ} \mathrm{C} \text { temperature for } 3 \text { hours }\end{array}$ & \multicolumn{3}{|c|}{ Wytrzymuje/ Withstands } & PN-56/C-04093 [12] \\
\hline 4. & $\begin{array}{c}\text { Stabilność strukturalna wydzielonego oleju w [\%]/Structural } \\
\text { stability of the separated oil in [\%] }\end{array}$ & - & $10^{1)}$ & $8^{1)}$ & $\mathrm{PN}-59 / \mathrm{C}-04136[13]$ \\
\hline 5. & $\begin{array}{l}\text { Zawartość substancji rysujących/ } \\
\text { The content of scratching substances }\end{array}$ & \multicolumn{3}{|c|}{ nie zawiera/ not contains } & PN-58/C-04142 [14] \\
\hline 6. & $\begin{array}{c}\text { Zawartość wolnych zasad w przeliczeniu } \mathrm{NaOH} \text { w [\%] nie } \\
\text { więcej niż/ The content of free alkales expressed in } \mathrm{NaOH} \text { in } \\
{[\%] \text { is not more than }}\end{array}$ & \multicolumn{3}{|c|}{0,2} & PN-68/C-04152 [15] \\
\hline 7. & $\begin{array}{c}\text { Zawartość wody [\%] nie więcej niż/ Water content [\%] is not } \\
\text { more than }\end{array}$ & 0,1 & 0,1 & 0,1 & PN-66/C-04523 [16] \\
\hline 8. & $\begin{array}{l}\text { Zawartość stałych ciał obcych [\%] nie więcej niż/ The content } \\
\text { of solid foreign bodies [\%] is not more than }\end{array}$ & 0,4 & 0,4 & 0,5 & PN-55/C-04141[17] \\
\hline 9. & Zakres temperatur pracy/ Working temperature range & \multicolumn{3}{|c|}{$-30^{\circ} \div+120^{\circ} \mathrm{C}$} & $\begin{array}{c}\text { zgodnie z pkt.1.2 } \\
\text { normy PN-72/C-96134 } \\
{[10] / \text { according to }} \\
\text { pkt.1.2 of PN-72/C- } \\
96134 \text { standard[10] } \\
\end{array}$ \\
\hline 10. & Odporność na działanie wody/Water resistance & \multicolumn{3}{|c|}{ Tak/Yes } & $\begin{array}{c}\text { zgodnie z pkt.1.2 } \\
\text { normy PN-72/C-96134 } \\
{[10] / \text { according to }} \\
\text { pkt.1.2 of PN-72/C- } \\
96134 \text { standard [10] } \\
\end{array}$ \\
\hline 11. & Tekstura/ Texture & \multicolumn{3}{|c|}{ Gładka/Smooth } & $\begin{array}{c}\text { zgodnie z pkt.3.2 } \\
\text { normy PN-72/C-96134 } \\
{[10] / \text { according to }} \\
\text { pkt.3.2 of PN-72/C- } \\
96134 \text { standard [10] } \\
\end{array}$ \\
\hline 12. & Dodatkowe wymagania/ Additional requirements & \multicolumn{3}{|c|}{$\begin{array}{l}\text { Smary powinny być jednorodne, bez } \\
\text { grudek o barwie jasno lub } \\
\text { ciemnobrunatnej/ Greases should be } \\
\text { homogeneous, without lumps of light or } \\
\text { dark brown colour }\end{array}$} & $\begin{array}{c}\text { zgodnie z pkt.3.2 } \\
\text { normy PN-72/C-96134 } \\
{[10] / \text { according to }} \\
\text { pkt.3.2 of PN-72/C- } \\
96134 \text { standard[10] }\end{array}$ \\
\hline 13. & Zagęszczanie/ Thickening & \multicolumn{3}{|c|}{$\begin{array}{c}\text { Mydłami litowo-wapniowymi/ Lithium- } \\
\text { lime soaps }\end{array}$} & $\begin{array}{c}\text { zgodnie z pkt.2.1 } \\
\text { normy PN-72/C-96134 } \\
{[10] / \text { according to }} \\
\text { pkt.2.1 of PN-72/C- } \\
96134 \text { standard [10] }\end{array}$ \\
\hline 14. & Przechowywanie/Storage & \multicolumn{3}{|c|}{$\begin{array}{l}\text { Smary plastyczne } € T \text { do łożysk tocznych } \\
\text { należy przechowywać w pomieszczeniu } \\
\text { suchym, zabezpieczonym przed } \\
\text { bezpośrednim działaniem promieni } \\
\text { słonecznych w temperaturze nie } \\
\text { przekraczającej }+30^{\circ} \mathrm{C} \text {. Przy } \\
\text { przechowywaniu smaru w opakowaniu } \\
\text { dłużej niż rok smar należy poddać } \\
\text { badaniom zgodnie z p.1 } \div \text { p.8 (p.3.3 PN- } \\
72 / C-96134[10]) \text { i stosować go tylko pod } \\
\text { warunkiem zgodności z wymaganiami } \\
\text { ww. normy/ } € T \text { plastic greases for roller } \\
\text { bearings should be stored in a dry room, } \\
\text { protected from direct sunlight at a } \\
\text { temperature not exceeding }+30^{\circ} \mathrm{C} \text {. During } \\
\text { storage of grease in the packaging for } \\
\text { more than a year, the grease should be } \\
\text { tested in accordance with p.1 } \div \text { p.8 (p.3.3 } \\
\text { PN-72/C-96134 [10]) and used only if it } \\
\text { complies with the requirements of } \\
\text { above mentioned standard }\end{array}$} & $\begin{array}{c}\text { zgodnie z pkt.4.2 } \\
\text { normy PN-72/C-96134 } \\
{[10] / \text { according to }} \\
\text { pkt.4.2 of PN-72/C- } \\
96134 \text { standard [10] }\end{array}$ \\
\hline
\end{tabular}

1) do roku ustalenia tej normy przekroczenie tych wartości nie dyskwalifikuje smaru

1) until the year of setting this standard the exceeding of these values does not disqualify the grease 
However, the situation gradually changed to a disadvantage when the UIC 814 leaflet was introduced [2]. Together with this document, the necessity of grease approval appeared. ŁT43 grease, but also many greases from the well-known producers did not meet the requirements of this leaflet due to the very expensive stand and field tests. In 2007, the first edition of PN-EN 12081+A1:2007 [4] took place, which concerned the greases used in bearings built in the axle box bodies. In 2017 it was the next edition of this PNEN 12081:2017 standard [4]. It is paid attention to the fact that in both cases both editions of European standards regarding greases should be associated with editions of other directly related standards, i.e. PN-EN 12080:2007 [3] and 12082:2007 [5] as well as PN-EN 12080:2017 [3] and 12082:2017 [5]. The current situation may force the individual carriers to change their position and requirements for bearings and grease for compliance with the new editions of European standards. It is paid attention to the fact that rolling bearing grease should have a technical specification, where the following information should be included:

$>$ essential data concerning the application - bearing types, loads, ambient temperature, speed class and intended maintenance plan

$>$ approval level, i.e. full approval of type "C" or limited approval of type " $\mathrm{R}$ " and conditions

$>$ terms of delivery, packaging and marking

$>$ additional technical requirements, including data on safety and storage conditions

$>$ the required quality system, quality records and the possibility of identification,

$>$ for obtaining the approval, in-depth technical sheet of grease data and a safety data sheet in accordance with European legislation

$>$ additional technical requirements by which specific operating conditions are to be understood

$>$ required quality system tests, quality records and capability to identify

$>$ the results of approval tests

$>$ speed class for which the grease is approved

$>$ limitations of characteristics whose tolerances are not specified in Annex B of this standard

$>$ the method of assessing the anti-wear capability.

Full approval of type $C$ (four-stage) is described in the standard annex A.2, but the limited approval is described in Annex A.3 of PN-EN 12081: 2017 [4]. As it is seen from the presented requirements the grease is dedicated to the defined types of bearings with giving such parameters as load or speed. It can be concluded that "the route of the grease producer for using in the railways" was determined by specific stand and field tests and the necessity to obtain the approval.

\subsection{Operation problems of axle box bearings caused by improper lubrication}

Using the approved grease in bearings, for which the
Jednakże sytuacja stopniowo zmieniała się na niekorzyść, kiedy wprowadzono kartę UIC 814 [2]. Wraz z tym dokumentem pojawiła się konieczność homologacji smaru. Smar ŁT43, ale również wiele smarów znanych producentów nie spełniało wymagań tej karty z uwagi na bardzo kosztowne badania stanowiskowe i poligonowe. W roku 2007 doszło do pierwszej edycji PN-EN 12081+A1:2007 [4], która dotyczyła smarów stosowanych w łożyskach zabudowanych w korpusach maźnic. W 2017 roku doszło do kolejnej edycji tej normy PN-EN 12081:2017 [4]. Zwraca się uwagę na fakt, że w obydwu przypadkach obydwie edycje norm europejskich, dotyczących smarów, należy kojarzyć z edycjami innych norm bezpośrednio związanych tzn. PN-EN 12080:2007 [3] i 12082:2007 [5] oraz PN-EN 12080:2017 [3] i 12082:2017 [5]. Obecna sytuacja może zmusić poszczególnych przewoźników do zmiany stanowiska i wymagń dla łożysk oraz smarów na zgodność z nowymi edycjami norm europejskich. Zwraca się uwagę na fakt, że smar do łożysk tocznych powinien posiadać specyfikację techniczna, gdzie powinny być zamieszczone następujące informacje:

$>$ istotne dane dotyczące stosowania-typy łożysk, obciążenia, temperatury otoczenia, klasy prędkości i zamierzony plan utrzymania

$>$ poziom homologacji, tzn. homologacja pełna typu „C" lub homologacja ograniczona typu „R” warunki

$>$ warunki dostawy, pakowania i oznakowania

$>$ dodatkowe wymagania techniczne, $w$ tym dane dotyczące bezpieczeństwa i warunków przechowywania

>wymagany system jakości, zapisy dotyczące jakości i możliwość identyfikacji

$>$ warunki dostawy, pakowania i oznakowania

$\nu_{\mathrm{w}}$ celu uzyskania homologacji, wyczerpujący arkusz danych technicznych smaru i arkusz danych dotyczących bezpieczeństwa zgodnie z prawodawstwem europejskim

$>$ dodatkowe wymagania techniczne, przez które rozumie się specyficzne warunki eksploatacji

$>$ wymagane badania systemu jakości, zapisy dotyczące jakości i zdolność do identyfikacji

$>_{\text {wyniki badań homologacyjnych }}$

$>$ klasa prędkości, dla której smar jest homologowany

$>$ ograniczenia charakterystyk, których tolerancje nie są określone w Załączniku B niniejszej normy

$>$ metoda oceny zdolności zapobiegania zużyciu.

Homologacja pełna typu C (czteroetapowa) jest opisana w załączniku normatywnym A.2, natomiast homologacja ograniczona jest opisana w załączniku A.3 normy PN-EN 12081:2017 [4]. Jak widać z przedstawionych wymagań smar jest dedykowany do określonych typów łożysk z podaniem takich parametrów jak obciążenia czy prędkość. Można wyciagnąć wniosek, 
tests were carried out, requires compliance with the basic rules for proper grease distribution. As it results from operational practice over $40 \%$ of damages of rolling bearings is caused by incorrect lubrication.

The main causes of damages caused by lubrication are:

$>$ unsuitable lubricant (oil with too low viscosity, no suitable additives)

$>$ deficiency of lubricant in the contact area of the surface

$>$ impurities in the lubricant center

$>$ change of grease properties

>xcessive lubrication.

Analyzing all of the above factors it can be determined first of all what may be the reason for the appearance of impurities in the grease, which may occur at the stage:

$>$ grease production

$>$ transport and storage of grease

$>$ introducing of grease into dirty bearings, which may already be at the stage of production of the final vehicle

$>$ improper sealing work during operation

$>$ performing the simplified ultrasound tests during the operation of the rail vehicle, where the front cover is removed and the pressure ring is unscrewed and thus the bearings are exposed to impurities entering the inside of the axle box body with bearings; however it is unacceptable to perform any ultrasonic tests in field conditions or in the dirty rooms exposing the bearings (bearing set) to the penetration of solid impurities or humid air

$>$ during repairs of railway vehicles, where there is a dismantling of wheelsets; in this case, the washing process of the bearings, the axle box body and the remaining parts of the axle box should be carried out in a professional and precise way if a replacement of the grease is to be made; mixing old and new grease is not permitted.

herefore, it should be taken into account that the basis for the correct operation of the bearings is, apart from meeting other conditions, the selection of an approved grease, but on condition that the principles of cleanliness are followed.

It follows from this that the room in which the assembly is carried out and built in the body of the axle box should meet the following requirements, namely:

$>$ it should be clean

$>$ it should have controlled temperature and humidity

$>$ it should be protected against uncontrolled breeze of air from outside regardless of the season

$>$ it should be equipped and used for the purpose for which it is intended

$>$ it should be reserved for the staff directly performing the above-mentioned work and controlling the quality of work. że „droga producenta smaru do zastosowania w kolejnictwie" została uwarunkowana konkretnymi badaniami stanowiskowymi oraz poligonowymi oraz koniecznością uzyskania homologacji.

\subsection{Problemy eksploatacyjne lożysk maźniczych spowodowane niewłaściwym smarowaniem}

Stosowanie smaru homologowanego w łożyskach, dla których przeprowadzono testy wymagają jednak przestrzegania podstawowych zasad związanych z właściwym rozprowadzeniem smaru. Jak wynika z praktyki eksploatacyjnej ponad $40 \%$ uszkodzeń łożysk tocznych jest wywołane niewłaściwym smarowaniem.

Głównymi przyczynami uszkodzeń wywołanych smarowaniem są:

$>$ nieodpowiedni środek smarowy (olej o zbyt niskiej lepkości, brak odpowiednich dodatków)

$>$ niedobór środka smarowego $\mathrm{w}$ obszarze styku powierzchni

zanieczyszczenia w ośrodku smarowym

$>$ zmiany własności smaru

$>$ nadmierne smarowanie.

Analizując wszystkie ww. czynniki można przede wszystkim ustalić co może być przyczyną pojawienia się zanieczyszczeń w smarze, które mogą powstać na etapie:

$>$ produkcji smaru

$>$ transportu i przechowywania smaru

$>$ wprowadzania smaru do zanieczyszczonych łożysk, co może stać się już na etapie produkcji pojazdu finalnego

$>$ niewłaściwej pracy uszczelnienia podczas eksploatacji

$>$ wykonywania uproszczonych badań ultradźwiękowych podczas eksploatacji pojazdu szynowego, gdzie dochodzi do demontażu pokrywy przedniej i odkręcenia pierścienia dociskowego i tym samym do narażenia łożysk na wnikanie zanieczyszczeń do wnętrza korpusu maźnicy z łożyskami; niedopuszczalne jest wykonywanie jakichkolwiek badań ultradźwiękowych w warunkach poligonowych lub w pomieszczeniach zabrudzonych, narażając łożyska (zespół łożysk) na wnikanie zanieczyszczeń stałych lub wilgotnego powietrza

$>$ podczas napraw pojazdów szynowych, gdzie dochodzi do rozmaźnicowania zestawów kołowych; w tym przypadku należy przeprowadzić w sposób profesjonalny i dokładny proces mycia łożysk, korpusu maźnicy oraz pozostałych części maźnicy, jeśli zamierza się wykonać wymianę smaru na nowy; niedopuszczalne jest mieszanie smaru starego z nowym.

W związku z tym należy wziąć pod uwagę, że podstawą do prawidłowej pracy łożysk, jest oprócz spełnienia innych warunków, dobór homologowanego smaru, ale pod warunkiem zachowania zasad czystości. 
From the assessment of cleanliness of the room, the factor of subjective human assessment should be completely excluded, but the PN-EN ISO 14644 standard [7] should be used, in which objective criteria for assessing the cleanliness of the room can be found. From the industrial practice it appears that the room, where the dismantling of axle boxes and bearings is carried out, should be separated from the room in which the opposite operation is carried out.

As it appears from the manual, developed by FAG company "Assembly of cylindrical roller bearings" WL $80102 / 2 D A$ [19], already the small particles of impurities, penetrating into the bearing area, lead to wear of the race. For this reason, the assembly place should be clean and dry. Similar conditions should be provided during periodic repairs. According to the above publication the impurities can be divided into solid and liquid.

The assessment of the impurities risk that may occur in the grease should be assessed according to the following criteria:

$>$ type and hardness of impurities

$>$ the degree of concentration of impurities in the lubricant

$>$ particle size of impurities.

Metal filings, abrasive filings, dust, moulding sand and corundum (solid impurities) as well as acids, alkalis, solvents and water (liquidimurities), which can appear in the grease, may be included to the its impurities. In FAG WL 82102/2DA publication [19] there is an appropriate graph, which determines the reduction of relative life, caused by the occurrence of various types of impurities (Fig.1).

In publications, developed by the basic producers of bearings, intended for rolling stock, it is not given what size of impurities is dangerous for bearing work.

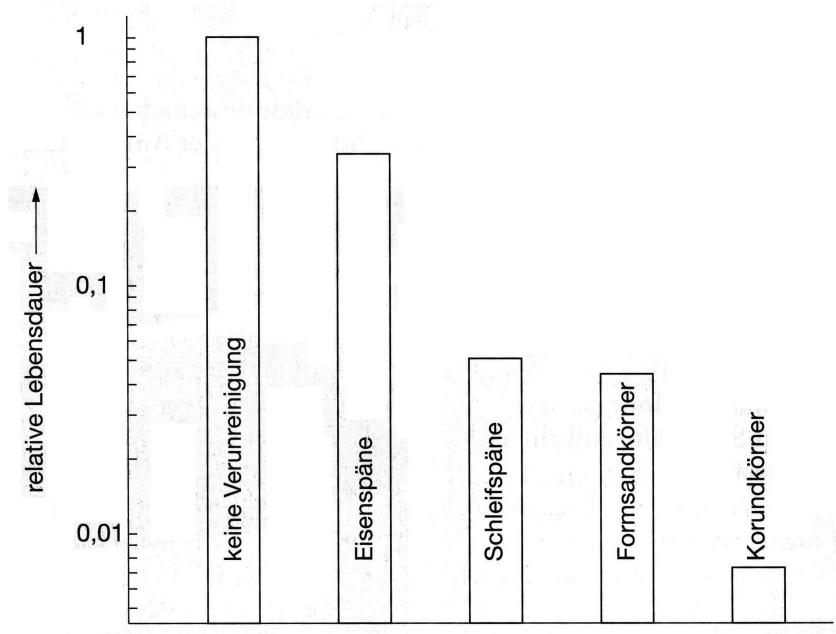

Fig.1. Reduction of bearing life (bearings set) by various impurities according to FAG WL 82 102/2DA publication [19]] Rys. 1. Zmniejszenie żywotności łożysk (zespołu łożysk) przez różne zanieczyszczenia wg publikacji FAG WL 82 102/2DA [19]
Z tego wynika, że pomieszczenie, w którym dokonuje się montażu i zabudowanych w korpusie maźnicy, powinno spełniać następujące wymagania, mianowicie:

$>$ powinno być czyste

$>$ powinno posiadać kontrolowaną temperaturę oraz wilgotność

$>$ powinno być zabezpieczone przed niekontrolowanymi powiewami powietrza z zewnątrz niezależnie od pory roku

$>$ powinno być wyposażone i wykorzystywane do celu, do jakiego jest przeznaczone

$>$ powinno być zastrzeżone dla personelu bezpośrednio wykonującego ww. prace oraz kontrolującego jakość wykonywanych prac.

Z oceny czystości pomieszczenia należy wylączyć kompletnie czynnik subiektywnej oceny ludzkiej, natomiast posłużyć się normą PN-EN ISO 14644 [7], w której można znaleźć obiektywne kryteria oceny czystości pomieszczenia. $Z$ praktyki przemysłowej wynika, że pomieszczenie, w którym dokonuje się operacji demontażu maźnic oraz łożysk, powinno być oddzielone od pomieszczenia, w którym wykonuje się operację odwrotną.

Jak wynika z podręcznika, opracowanego przez firmę FAG „Montaż łożysk walcowych” WL 80 102/2DA [19], już małe cząstki zanieczyszczeń, wnikając w obszar łożysk, doprowadzają do zużycia bieżni. Z tego też względu miejsce montażu powinno być czyste $\mathrm{i}$ suche. Podobne warunki należy zapewnić podczas napraw okresowych. Zgodnie z ww. publikacją zanieczyszczenia można podzielić na stałe oraz na ciekłe.

Ocenę zagrożenia zanieczyszczeniami, które mogą pojawić się w smarze należy oceniać wg następujących kryteriów:

$>$ rodzaj i twardość zanieczyszczeń

$>$ stopień koncentracji zanieczyszczeń w środku smarnym

$>$ wielkość cząsteczek zanieczyszczeń.

Do zanieczyszczeń smaru, które mogą się w nim pojawić można zaliczyć opiłki metalowe, opiłki ścierne, kurz, piasek formierski i korund (zanieczyszczenia stałe) oraz kwasy, zasady, rozpuszczalniki i woda (zanieczyszczenia ciekłe). W publikacji FAG WL 82102/2DA [19] znajduje się odpowiedni wykres, który określa zmniejszenie się żywotności względnej, spowodowanej występowaniem różnego rodzaju nieczystości (rys.1).

W publikacjach, opracowanych przez podstawowych producentów łożysk, przeznaczonych do taboru kolejowego nie podaje się, jaka wielkość zanieczyszczeń jest groźna dla pracy łożyskowej.

Jak wynika z praktyki eksploatacyjnej, przyczyny uszkodzenia łożysk można $\mathrm{w}$ udziale procentowym podzielić w sposób następujący: 


\section{Legenda:/Legend:}

Oś rzędnych/ Axis of ordinates - niem. „relative Lebensdauer”żywotność względna,/ Geman "relative Lebensdauer" - relative life niem. ,kleine Verunreinigung”- małe zanieczyszczenia,/ German. ,kleine Verunreinigung”- small impurities niem. „Eisenspäne”- wióry stalowel German. „Eisenspäne”- steel shavings niem. „Schleifspäne"-wióry, pochodzace od procesu szlifowanial German. „Schleifspäne”-shavings, coming from grinding process niem. „Formsandkörner”-ziarna piasku formierskiego/ German „,Formsandkörner"-grains of moulding sand niem. „Korundkörner”- ziarna korundu/ German. „Korundkörner”- grains of corundum.

As it results from the operational practice, the causes of bearing damage can be divided in the percentage contribution as follows:

$>$ unsuitable lubricant - $20 \%$

$>$ aging of the grease $-20 \%$

$>$ solid impurities $-20 \%$

$>$ deficiency of lubrication (grease) - $15 \%$

$>$ inappropriate choice of bearing (construction, size, bearing capacity) - $10 \%$

$>$ assembly errors - $5 \%$

$>$ liquid impurities - $5 \%$

$>$ assembly errors - $5 \%$

$>$ indirect damages - $5 \%$

$>$ assembly and execution errors $<1 \%$.

In publications developed by the basic producers of bearings, intended for rolling stock, it is usually given very precisely what size of impurities is dangerous for bearing work.

It can be assumed from the FAG Publ.-No. 81115 PIA publication [18] that impurities of $0,1 \mathrm{~mm}$ can be considered as critical. It is a size that is recognized in practice as such, which, getting in the cooperating parts, causes the permanent deformations on the outer surfaces of the race. In the places of the race, where permanent deformations occur, with each rolling of the rollers as rolling parts, there is the bigger and bigger surface pressures on the contact surface of the roller-race of the bearing, which in turn causes the gradual lowering of the bearing material fatigue limit. The leading companies producing the bearings for industry and rolling stock operate with the purity factor "s", which present quantitatively the impact of pollutants on durability.

In order to determine the purity factor ,s" the impurity parameter , $\mathbf{V}$ " is needed, and thus:

$>$ for increased purity $\mathbf{V}=\mathbf{0 , 5}$ and highest purity $\mathbf{V}=\mathbf{0 , 3}$, the purity factor is $\mathbf{s} \geq \mathbf{1}$

$>$ for normal purity i.e. $\mathbf{V}=\mathbf{1}$, it is always applied $\mathbf{s}=\mathbf{1}$

$>$ for a moderately impure lubricant $\mathbf{V}=\mathbf{2}$, the purity factor is $\mathbf{s}<\mathbf{1}$

$>$ for a strong impure lubricant $\mathbf{V}=\mathbf{3}$, the purity factor is $\mathbf{s}<\mathbf{1}$.

The pollution parameter $\mathrm{V}$ of the lubricant depends on the cross-section of the bearing, type of bearing contact and oil cleanliness class. The smaller contact surface (on the rolling surface in the race - roller system),
$>$ nieodpowiedni środek smarny - $20 \%$

$>$ starzenie się smaru - $20 \%$

$>$ zanieczyszczenia stałe - $20 \%$

$>$ niedobór smarowania (smaru) - $15 \%$

$>$ nieodpowiedni dobór łożyska (budowa, wielkość, nośność łożyska) - $10 \%$

$>$ błędy montażowe - $5 \%$

$>$ zanieczyszczenia ciekłe - $5 \%$

$>$ błędy montażowe - $5 \%$

$>$ szkody pośrednie - $5 \%$

$>$ błędy montażowe i wykonawcze $<1 \%$.

W publikacjach, opracowanych przez podstawowych producentów łożysk, przeznaczonych do taboru kolejowego, zwykle podaje się bardzo precyzyjnie, jaka wielkość zanieczyszczeń jest groźna dla pracy łożyskowej.

Można wyjść z założenia na podstawie publikacji FAG Publ.-Nr 81115 PIA [18], że zanieczyszczenia o wielkości $0,1 \mathrm{~mm}$, można uznać już za krytyczne. Jest to wielkość, która jest uznawana w praktyce jako taka, która dostając się w części współpracujące, powoduje odkształcenia trwałe na powierzchniach zewnętrznych bieżni. W miejscach bieżni, gdzie występują odkształcenia trwałe, przy każdym przetoczeniu wałeczków, jako części tocznych, dochodzi do coraz większych nacisków powierzchniowych na powierzchni kontaktowej wałeczek-bieżnia łożyska, co z kolei powoduje stopniowe obniżanie granicy zmęczenia materiału łożyskowego. Czołowe firmy produkujące łożyska dla przemysłu oraz taboru kolejowego, operują współczynnikiem czystości „s”, który ujmuje ilościowo wpływ zanieczyszczeń na trwałość.

W celu wyznaczenia współczynnika czystości „,s” jest potrzebny parametr zanieczyszczenia ,V”, i tak:

$>$ dla zwiększonej czystości $\mathbf{V}=\mathbf{0 , 5}$ i najwyższej czystości $\mathbf{V}=\mathbf{0}, \mathbf{3}$, współczynnik czystości wynosi $\mathbf{s} \geq \mathbf{1}$

$>$ dla normalnej czystości, tzn. $\mathbf{V}=\mathbf{1}$, obowiązuje zawsze $\mathbf{s}=1$

$>$ dla umiarkowanie zanieczyszczonego środka smarnego $\mathbf{V = 2}$, współczynnik czystości wynosi $\mathbf{s}<\mathbf{1}$

$>$ dla silnego zanieczyszczonego środka smarnego $\mathbf{V = 3}$, współczynnik czystości wynosi $\mathbf{s}<\mathbf{1}$.

Parametr zanieczyszczenia $\mathbf{V}$ środka smarnego zależy od przekroju łożyska, rodzaju styku łożyska i od klasy czystości oleju. Im mniejsza jest powierzchnia styku (na powierzchni tocznej w układzie wałeczki-bieżnia), tym bardziej jest szkodliwe działanie cząstek zanieczyszczenia o określonej wielkości [21].

Jeśli uznać, że niedobór lub nadmiar smaru może być przyczyną wadliwej pracy łożyska to należy przeanalizować, jakie wielkości wyjściowe smaru są wyznaczone w dokumentacji konstrukcyjnej, kiedy układ biegowy jest na etapie wytwarzania. Jak wynika $\mathrm{z}$ dokumentacji konstrukcyjnej maźnic standardowych układów biegowych rodziny Y25, przeznaczonych dla wagonów towarowych, ilość smaru, który przypada na 
the more harmful effect of impurity particles of a definite size is [21].

If it is recognized that a deficiency or excess of grease can cause the malfunction of bearing, it is necessary to analyze what output values of the grease are determined in the constructional documentation when the running gear system is at the stage of production. As it appears from the constructional documentation of axle boxes of Y25 family's standard running gears systems for freight wagons, the amount of grease that is for one axle box/ one set of bearings NJ+NJP $120 \times 240 \times 80$ or $\mathrm{NJ}+\mathrm{NJP} 130 \times 240 \times 80$ is $1,6 \mathrm{~kg}$. Figure 2 presents the constructional solution of the axle box of standard Y25 family bogies.

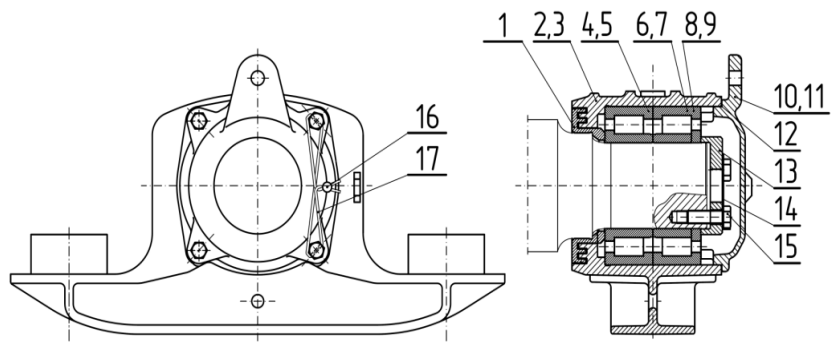

Fig. 2. Solution of axle box of Y25family bogies

Rys. 2. Rozwiązanie maźnicy wózków rodziny Y25 jedną maźnice/ jeden zestaw łożysk NJ+NJP $120 \times 240 \times 80$ lub NJ+NJP $130 \times 240 \times 80$ wynosi $1,6 \mathrm{~kg}$. $\mathrm{Na}$ rysunku2 przedstawiono rozwiązanie konstrukcyjne maźnicy wózków standardowych rodziny Y25.

Dane dotyczące prędkości obrotowych dla różnych prędkości liniowych wagonu towarowego wyposażonego w standardowe wózki Y25 z maźnicami z rys.2, przedstawiono w tablicy 2.

\section{Legenda/ Legend:}

1 - pierścień oporowy labiryntowy/labyrinth supporting ring

2, 3 - korpus maźnicy wykonany odpowiednio ze staliwa lub żeliwa sferoidalnego/ axle box body suitably made of cast steel or sheroidal iron

4, 5 - tożysko tylne NJ120×240×80 dla osi z czopem 120p6, NJ130×240×80 dla osi z czopem $130 \mathrm{p} 6 /$ rear bearing $N J 120 \times 240 \times 80$ for axle with

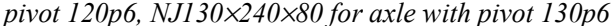

6, 7 - tożysko przednie NJP $\times 120 \times 240 \times 80$ dla osi z czopem 120p6, NJP $130 \times 240 \times 80$ dla osi $z$ czopem 130p6/ front bearing NJP $\times 120 \times 240 \times 80$ for axle with pivot $120 p 6$, NJP $130 \times 240 \times 80$ for axle with pivot $130 \mathrm{p} 6$,

8, 9 - komplet tożysk NJ+NJP lub WJ+WJP 120×240×80 dla osi z czopem 120p6, NJ+NJP lub WJ+WJP $130 \times 240 \times 80$ dla osi z czopem $130 \mathrm{p} 6 / \mathrm{set}$ of bearings $N J+N J P$ or $W J+W J P 120 \times 240 \times 80$ for axle with pivot $120 \mathrm{p} 6, \mathrm{NJ}+\mathrm{NJP}$ or $W J+W J P 130 \times 240 \times 80$ for axle with pivot $130 p 6$

10, 11 - pokrywa przednia ze staliwa lub żeliwal front cover made of cast steel or cast iron

12 - uszczelka gumowa/ rubber gasket

13 - pierścień dociskowy/ pressure ring

14 - podkladka zabezpieczajaca/ security washer

15 - śruby mocujacel fixing screws

16 - plomba/ seal

17 - drut stalowy/ steel wire.

Zestawienie prędkości obrotowych lożysk dla różnych prędkości liniowych dla wagonu towarowego wyposażonego w wózki Y25/ List of rotational speeds of bearings for various linear speeds for the freight wagon equipped with Y25 bogies

Tablica 2/Table 2

\begin{tabular}{|c|c|c|c|c|c|c|c|}
\hline 1 & 2 & 3 & 4 & 5 & 6 & 7 & 8 \\
\hline $\begin{array}{l}\text { Prędkość liniowa pojazdu/ Linear speed } \\
\text { of vehicle }\end{array}$ & $20 \mathrm{~km} / \mathrm{h}$ & $40 \mathrm{~km} / \mathrm{h}$ & $60 \mathrm{~km} / \mathrm{h}$ & $80 \mathrm{~km} / \mathrm{h}$ & $90 \mathrm{~km} / \mathrm{h}$ & $100 \mathrm{~km} / \mathrm{h}$ & $120 \mathrm{~km} / \mathrm{h}$ \\
\hline \multirow{4}{*}{$\begin{array}{l}\text { Prędkość obrotowa łożysk dla koła o } \\
\text { średnicy tocznej } 0,920 \mathrm{~m} / \text { Rotational speed } \\
\text { of bearings for wheel with } 0.920 \mathrm{~m} \text { rolling } \\
\text { diameter }\end{array}$} & \multicolumn{7}{|c|}{ [obr./sek]/ r.p.s } \\
\hline & 1,92 & 3,84 & 5,76 & 7,68 & 8,64 & 9,61 & 11,53 \\
\hline & \multicolumn{7}{|c|}{ [obr./min]/ r.p.m } \\
\hline & 115 & 230 & 346 & 461 & 519 & 577 & 692 \\
\hline $\begin{array}{l}\text { Liczba obrotów dla przebiegu } 25000 \mathrm{~km} / \\
\text { The number of rotations for the distance of } \\
25000 \mathrm{~km}\end{array}$ & \multicolumn{7}{|c|}{$8,62 \times 10^{6}$} \\
\hline $\begin{array}{l}\text { Liczba obrotów dla przebiegu w skali } \\
\text { rocznej } 400000 \mathrm{~km} / \text { The number of rota- } \\
\text { tions for the annual distance of } 40000 \mathrm{~km}\end{array}$ & \multicolumn{7}{|c|}{$13,8 \times 10^{6}$} \\
\hline $\begin{array}{l}\text { Prędkość liniowa pojazdu/ Linear speed } \\
\text { of vehicle }\end{array}$ & $20 \mathrm{~km} / \mathrm{h}$ & $40 \mathrm{~km} / \mathrm{h}$ & $60 \mathrm{~km} / \mathrm{h}$ & $80 \mathrm{~km} / \mathrm{h}$ & $90 \mathrm{~km} / \mathrm{h}$ & $100 \mathrm{~km} / \mathrm{h}$ & $120 \mathrm{~km} / \mathrm{h}^{1)}$ \\
\hline \multirow{4}{*}{$\begin{array}{l}\text { Prędkość obrotowa łożysk dla koła o } \\
\text { średnicy tocznej } 0,870 \mathrm{~m} / \text { Rotational speed } \\
\text { of bearings for wheel with } 0.870 \mathrm{~m} \text { rolling } \\
\text { diameter }\end{array}$} & \multicolumn{7}{|c|}{ [obr./sek]/ r.p.s. } \\
\hline & 2,03 & 4,06 & 6,09 & 8,13 & 9,14 & 10,16 & 12,19 \\
\hline & \multicolumn{7}{|c|}{ [obr./min]/ r.p.m } \\
\hline & 122 & 244 & 366 & 488 & 549 & 610 & 731 \\
\hline $\begin{array}{l}\text { Liczba obrotów łożysk dla przebiegu w } \\
\text { skali rocznej } 25000 \mathrm{~km} / \text { The number of } \\
\text { rotations for the annual distance of } 25000 \\
\mathrm{~km}\end{array}$ & \multicolumn{7}{|c|}{$9,15 \times 10^{6}$} \\
\hline $\begin{array}{l}\text { Liczba obrotów łożysk dla przebiegu w } \\
\text { skali rocznej } 400000 \mathrm{~km} / \text { The number of } \\
\text { rotations for the annual distance of } 40000 \\
\mathrm{~km}\end{array}$ & \multicolumn{7}{|c|}{$14,64 \times 10^{6}$} \\
\hline
\end{tabular}


1) dotyczy wagonów, wyposażonych $w$ gniazdo skrętu z tworzywa sztucznego oraz w ślizgi sprężyste z wkładkami z
tworzywa sztucznego
2) applies to wagons equipped with the plastic bogie pivot and elastic slides with plastic inserts

Rotational speed data for the various linear speeds of freight wagon equipped with standard Y 25 bogies with axle boxes in Figure 2 are presented in Table 2.

As it is seen from the data collected in Table 2 the rotational speeds have variable values for different rotational speeds. If it is taken according to $\mathrm{BN}-$ 71/1131-7 [8] that the specific dynamic capacity of bearing of NJ +NJP $130 \times 240$ is $48000 \mathrm{daN}$ for each of them (for NJ+NJP $120 \times 240$ the specific dynamic capacity of bearing is $42000 \mathrm{daN}$, the estimated the substitute load is $6945 \mathrm{daN}$.

In this case, the durability expressed in years (for all distances in the loaded condition) is respectively:

$>38$ years for an annual distance of $25000 \mathrm{~km}$ (new state of wheel)

$>24$ years for an annual distance of $40000 \mathrm{~km}$ (new state of wheel)

$>36$ years for an annual distance of $25000 \mathrm{~km}$ (worn state of wheel)

$>22,5$ years for an annual distance of $40000 \mathrm{~km}$ (worn state of wheel).

From this it follows that the average durability expressed in years is approximately 30 years. This average value is more justified because the rotational speed increases as the rolling diameter decreases. The rolling diameter in the new state and the rolling diameter in the worn state are more extreme diameters, which determine a certain range of wheel use. It can further be concluded that the distances in the empty state are not as important for bearing life because the substitute loads are four times lower in this case (the weight of the wagon in the empty state is about 20000 $\mathrm{kg}$, but in the loaded state is $80000 \mathrm{~kg}$. Apart from the fact that the calculations are simplified, but the degree of simplification is not so important here, that the obtained result cannot differ much from the actual one. In Table 1 of BN-71/1137-07 standard [8] it is given that the required bearing life for freight wagons is not less than $10^{6}$ in $\mathrm{km}$. If so, the obtained values, by means of simplified calculations, indicate the similar bearing durability, expressed in years i.e. $38 \times 25000$ $\mathrm{km}=950000 \mathrm{~km}=0,95 \times 10^{6} \mathrm{~km}, 24 \times 40000 \mathrm{~km}=960000$ $\mathrm{km}=0,96 \times 10^{6} \mathrm{~km}, 36 \times 25000=900000=0,9 \times 10^{6} \mathrm{~km}$ and $22,5 \times 40000=900000=0,9 \times 10^{6} \mathrm{~km}$. Another an important issue is not assumed milage per year, and the actual milage of a wagon. It should be assumed that the more distance per year, the bigger need for repairs and inspections, especially in the field of axle box and bearings. Therefore, it becomes more logical to carry out the repairs depending on the actual technical state of the vehicle than carrying out the compulsory periodic repairs. It should be also paid attention to the fact that currently produced bearings have much longer durability, but bearings $\mathrm{NJ}+\mathrm{NJP}$
Jak widać $\mathrm{z}$ danych, zgromadzonych $\mathrm{w}$ tablicy 2, prędkości liniowe mają zmienne wartości dla różnych prędkości obrotowych. Jeśli przyjąć zgodnie z BN71/1131-7 [8], że nośność ruchowa łożysk NJ +NJP $130 \times 240$ wynosi dla każdego z nich 48000 daN (dla NJ+NJP 120×240 nośność ruchowa wynosi 42000 daN, to oszacowane obciążenie zastępcze wynosi 6945 daN.

W takim razie trwałość wyrażona $\mathrm{w}$ latach wynosi odpowiednio (dla wszystkich przebiegów w stanie ładownym) wynosi odpowiednio:

$>38$ lat dla przebiegu rocznego $25000 \mathrm{~km}$ (stan nowy koła)

$>24$ lata dla przebiegu rocznego $40000 \mathrm{~km}$ (stan nowy koła)

$>36$ lat dla przebiegu rocznego $25000 \mathrm{~km}$ (stan zużyty koła)

$>22,5$ lat dla przebiegu rocznego $40000 \mathrm{~km}$ (stan zużyty koła).

Z tego wynika, że średnia trwałość wyrażona w latach wynosi około 30. Ta średnia wartość jest bardziej uzasadniona, gdyż prędkość obrotowa zwiększa się wraz ze zmniejszaniem się średnicy tocznej. Średnica toczna w stanie nowym oraz średnica toczna w stanie zużytym są bardziej krańcowymi średnicami, które wyznaczają pewien przedział użytkowania koła. Dalej można wnioskować, że przebiegi w stanie próżnym nie mają aż takiego znaczenia dla trwałości łożyska, ponieważ obciążenia zastępcze są $\mathrm{w}$ tym przypadku czterokrotnie niższe (masa wagonu w stanie próżnym wynosi około $20000 \mathrm{~kg}$, natomiast w stanie ładownym $80000 \mathrm{~kg}$. Pomijając fakt, że obliczenia mają charakter uproszczony, ale stopień uproszczenia nie ma tutaj aż takiego znaczenia, że otrzymany wynik niewiele może różnić się $\mathrm{w}$ tym przypadku od rzeczywistego. W tablicy 1 normy BN-71/1137-07 [8] jest podana wymagana trwałość łożysk dla wagonów towarowych, wynosząca nie mniej niż $10^{6} \mathrm{w} \mathrm{km}$. Jeśli tak, to wartości otrzymane, drogą obliczeń uproszczonych, wskazują na zbliżoną trwałość łożysk, wyrażona w latach, tzn. $38 \times 25000 \mathrm{~km}=950000 \mathrm{~km}=0,95 \times 10^{6}$ $\mathrm{km}, \quad 24 \times 40000 \mathrm{~km}=960000 \mathrm{~km}=0,96 \times 10^{6} \mathrm{~km}$, $36 \times 25000=900000=0,9 \times 10^{6} \quad \mathrm{~km} \quad$ oraz $22,5 \times 40000=900000=0,9 \times 10^{6} \mathrm{~km}$. Kolejnym ważnym zagadnieniem jest nie założony przebieg kilometrowy w skali rocznej, a rzeczywisty przebieg wagonu. Należy wyjść z założenia, że im większy przebieg kilometrowy w skali rocznej, tym większe jest zapotrzebowanie na wykonanie napraw i przeglądów zwłaszcza w zakresie maźnicy i łożysk. Stąd bardziej logiczne staje się wykonywanie napraw

w zależności od rzeczywistego stanu technicznego pojazdu niż wykonywanie obowiązkowych napraw okresowych. Należy zwrócić dodatkowo uwagę na 
$120 \times 240$ or $\mathrm{NJ}+\mathrm{NJP} 130 \times 240$ produced by Polish factories before 1989 have been using on large-scale to this day. Table 3 gives the bearing durability values for other types of vehicles, which are shown in $\mathrm{BN}$ 71/1131-07 [8]. fakt, że obecnie produkowane łożyska mają znacznie większą trwałość, ale do dzisiaj użytkowane są i to w bardzo dużej skali łożyska NJ+NJP $120 \times 240$ lub NJ+NJP $130 \times 240$ wyprodukowane przez polskie wytwórnie przed 1989 rokiem. W tablicy 3 podano wartości trwałości łożysk dla innych rodzajów pojazdów, które są przedstawione w BN-71/1131-07 [8].

Trwałość lożysk dla różnych rodzajów pojazdów wg BN-71/1131-07 [8]/ Bearing life for various types of vehicles according to $\mathrm{BN}-\mathbf{7 1 / 1 1 3 1 - 0 7}[8] /$

Tablica 3/ Table 3

\begin{tabular}{|c|l|c|}
\hline Lp./ Item & \multicolumn{1}{|c|}{ Rodzaj pojazdu szynowego/ Type of rail vehicle } & $\begin{array}{c}\text { Obliczeniowa trwalość nie mniej- } \\
\text { sza niż }[\mathbf{k m}] / \text { Computational } \\
\text { durability not less than [km] }\end{array}$ \\
\hline 1. & $\begin{array}{l}\text { Zespoły trakcyjne spalinowe i elektryczne dalekobieżne oraz wag- } \\
\text { ony osobowe/ Long-distance electric and diesel traction units of } \\
\text { railway rolling stock as well as passenger wagons }\end{array}$ & 3000000 \\
\hline 2. & $\begin{array}{l}\text { Lokomotywy spalinowe i elektryczne liniowe i uniwersalne/ Regu- } \\
\text { lar and universal diesel and electric locomotives }\end{array}$ & 2500000 \\
\hline 3. & $\begin{array}{l}\text { Zespoły trakcyjne dla komunikacji podmiejskiej/ Traction units of } \\
\text { railway rolling stock for suburban transport }\end{array}$ & 1500000 \\
\hline 4. & Lokomotywy spalinowe manewrowe/ Diesel shunting locomotives & 1000000 \\
\hline 5. & Wagony towarowe/ Freight wagons & 1000000 \\
\hline
\end{tabular}

An additional factor making hard the maintenance and repair processes is the fact in this case that the railway vehicle moves on the different routes with various degrees of maintenance and at different seasons of the year. Grease and bearings are "in closed circuit", taking place in the axle box body and in this state they are as if out of control of the specialized staff. As it was already mentioned, it is much easier to set the distance in $\mathrm{km}$ for locomotives and traction units. The durability of bearings with distance in $\mathrm{km}$ can be more connected. However, from the carried out calculations it results that the notion of durability without proper grease quality, lubrication during operation and the selection of a proper seal, which protects the bearings and lubricant against the interference of external factors, cannot be treated. Another important factor that does not make repairs easier, where the inspection of bearings is anticipated in the case of freight wagons, the lack of universal provisions on the pattern of ITN -30 issue $B$ [20]. An important challenge for producers and transport companies is the fact that the further use of bearings, that are equipped with brass baskets and fixed with steel bolts, is forbidden in accordance with p.10.1.2 PN-EN 12080: 2017 standard [3]. If it is assumed, interpreting the regulations, that this applies only to a new produced and modernized subject, and not already used, it is only partially satisfying for the users of rolling stock already approved by the individual railway authorities for placing into service. The problem of durability is another argument to gradually replace the bearings produced before 1989 for new ones at the repair level of P4 and P5 bearings.

The progress in the railway industry enforces the already widespread use of cylindrical roller bearings
Dodatkowym czynnikiem, utrudniającym procesy konserwacyjno-naprawcze jest w tym przypadku fakt, że pojazd kolejowy porusza się na różnych trasach o różnym stopniu utrzymania $\mathrm{i} \mathrm{w}$ różnych porach roku. Smar i łożyska są „w obiegu zamkniętym”, odbywającym się w korpusie maźnicy i w tym stanie są jakby poza kontrolą wyspecjalizowanego personelu. Jak już wspomniano, znacznie łatwiej jest ustalić przebieg kilometrowy w przypadku lokomotyw oraz zespołów trakcyjnych. Można bardziej powiązać trwałość łożysk z przebiegiem kilometrowym. $Z$ wykonanych obliczeń wynika jednak, że nie można traktować pojęcia trwałości bez właściwej jakości smaru, smarowania w czasie eksploatacji oraz doboru właściwego uszczelnienia, które chroni łożyska oraz środek smarny przed ingerencją czynników zewnętrznych. Kolejnym istotnym czynnikiem, który wcale nie ułatwia przeprowadzenia napraw, gdzie przewidziana jest rewizja łożysk, jest w przypadku wagonów towarowych, brak uniwersalnych przepisów na wzór ITN -30 wydanie B [20]. Istotnym wyzwaniem dla producentów oraz firm przewozowych jest fakt, że dalsze zastosowanie lożysk, które są wyposażone w koszyki mosiężne i mocowane za pomocą nitów stalowych jest zakazane zgodnie z p.10.1.2 normy PN-EN 12080:2017 [3]. Jeśli założyć, interpretując przepisy, że dotyczy to tylko nowego produkowanego oraz modernizowanego tematu, a nie już użytkowanego, jest to tylko częściowo satysfakcjonujące użytkujących tabor już wcześniej dopuszczony przez poszczególne zarządy kolejowe do eksploatacji. Problem trwałości jest kolejnym argumentem, aby na poziomie napraw P4 oraz P5 wymieniać stopniowo łożyska, wyprodukowane przed 1989 rokiem na nowe. 
equipped with polymer baskets, which guarantee not only less friction during the "rotary work" of the bearing, but they have a lower own weight. Bearings or sets of bearings belong to the unsprung masses of vehicle and any reduction in this range is a limitation of shock impact in the track-vehicle system.

\section{CONCLUSIONS}

1. The problem of grease used currently in the country must urgently be solved for compliance with the applicable regulations and PN-EN 12081:2017 [4], PN-EN 12080:2017[3] and PN-EN 12082:2017 standards [5]. It may be considered to adapt the currently used $\mathrm{LT}-43$ grease to the approval process for the compliance with the requirements of the European standard. Undoubtedly, this may contribute to the increase of the operational safety of the domestic rolling stock both at home and abroad. Such a solution could be considered as advantageous from the point of view of the national economy. The demand for grease (the more certified) would be relatively large. The approval tests should be carried out in consultation with the bearing and axle box body producers. Obtaining such a certificate, even though very expensive, would become a major breakthrough in the field of domestic production of certified products for the railways. This is certainly associated with the large tests costs. Otherwise, the Polish railways may be "gradually convicted" to replace grease produced outside our country.

2. The problem of grease and lubrication, which takes place in the axle box body cannot be considered in a selective, but comprehensive way due to the complexity of the phenomenon. From the carried out analysis it is shown that many factors influence the effectiveness of the lubrication, which bring, among others, the more and more effective sealing of the bearing system.

3. Another problem is the necessity to replace the bearings with new ones if the bearings, which were produced in the eighties and earlier, especially in the railway rolling stock, are used. This replacement must be carried out in a planned way so as not to reduce carrier transport potential. The necessity of replacing the bearings with new ones is due to the fact that such bearings have already exceeded their durability and the likelihood of damage rapidly increases. It should be taken into account that currently produced bearings, thanks to the progress in the field of producing technology and control processes, have the greater durability and, in addition, they are maintenance-free.

4. Due to the high dependence of lubrication effectiveness on impurities, the issue of cleanliness during assembly and bearing repairs should be considered. It is recommended that the ultrasonic tests, that are connected with the disassembly of parts located in
Postęp w kolejnictwie wymusza już powszechne stosowanie łożysk walcowych, wyposażonych w koszyki polimerowe, które gwarantują nie tylko mniejsze tarcie podczas „pracy obrotowej” łożyska, ale posiadaja mniejszą masę własną. Łożyska lub zestawy łożysk należą do mas nieusprężynowanych pojazdu i każde zmniejszenie $w$ tym zakresie jest ograniczeniem oddziaływania o charakterze udarowym w układzie torpojazd.

\section{WNIOSKI}

1.Problem smaru stosowanego obecnie w kraju należy pilnie rozwiązać zgodnie z obowiązującymi przepisami i normami PN-EN 12081:2017 [4], PN-EN 12080:2017[3] oraz PN-EN 12082:2017 [5] . Można rozważyć przystosowanie obecnie jeszcze stosowanego smaru ŁT-43 do procesu homologacji na zgodność z wymaganiami normy europejskiej. Niewątpliwie może się to przyczynić do wzrostu bezpieczeństwa eksploatacyjnego rodzimego taboru kolejowego, tak w kraju jak i zagranica. Takie rozwiązanie można by uznać za korzystne z punktu widzenia gospodarki krajowej. Zapotrzebowanie na smar (tym bardziej homologowany) byłoby relatywnie duże. Badania homologacyjne powinny być prowadzone $\mathrm{w}$ porozumieniu $\mathrm{z}$ producentem łożysk oraz korpusów maźniczych. Uzyskanie takiego certyfikatu, mimo że bardzo kosztowne, stałoby się istotnym przełomem w dziedzinie produkcji krajowej certyfikowanych produktów dla kolejnictwa. Wiąże się to na pewno z dużymi kosztami badawczymi. W przeciwnym razie polskie kolejnictwo może być „stopniowo skazane" na wymianę smaru, produkowanego poza granicami naszego kraju.

2.Problem smaru i smarowania, który odbywa się w korpusach maźniczych nie może być rozpatrywany w sposób selektywny lecz kompleksowy ze względu na złożoność zjawiska. Z przeprowadzonej analizy widoczny jest fakt, że na skuteczność smarowania ma wpływ wiele czynników, które sprowadzają się między innymi do coraz bardziej efektywnego uszczelniania układu łożyskowego.

3. Kolejnym problemem jest konieczność wymiany łożysk na nowe, jeśli są użytkowane łożyska, które były wyprodukowane w latach osiemdziesiatych i wcześniej, zwłaszcza w taborze kolejowym towarowym. Wymiana ta musi być przeprowadzona w sposób planowy, tak aby nie zmniejszać potencjału przewoźnika. Konieczność wymiany łożysk na nowe argumentuje się tym, że takie łożyska przekroczyły już swoją trwałość i prawdopodobieństwo wystapienia uszkodzenia gwałtownie wzrasta. Należy uwzględnić, że obecnie produkowane łożyska, dzięki postępowi $\mathrm{w}$ zakresie technologii wytwarzania oraz procesów kontrolnych, posiadają większą trwałość, a w dodatku są bezobsługowe. 
the front part of the axle box, be performed keeping the cleanliness conditions.
Z uwagi na dużą zależność efektywności smarowania od zanieczyszczeń, należy rozważyć kwestię czystości montażu oraz podczas napraw łożysk. Zaleca się, aby badania ultradźwiękowe, które wiążą się z demontażem części, znajdujących się w części przedniej maźnicy, wykonywać przestrzegając warunków czystości.

\section{Bibliography / Bibliografia}

[1] Sobaś M. Wpływ omaźnicowanych zestawów kołowych na bezpieczeństwo eksploatacyjne. Pojazdy Szynowe $\mathrm{nr} 4 / 2016$.

[2] Karta UIC 814. Warunki techniczne dotyczace homologacji oraz dostawy smarów przeznaczonych do smarowania maźnic tocznych pojazdów szynowych. 2-gie wydanie z 1.07.1988

[3] PN-EN 12080:2017. Kolejnictwo. Maźnice. Łożyska toczne.

[4] PN-EN 12081:2017. Kolejnictwo. Maźnice. Smary.

[5] PN-EN 12082:2017. Kolejnictwo. Maźnice. Badanie eksploatacyjne.

[6] PN-EN 15227+A1:2017. Kolejnictwo - Wymagania zderzeniowe dla pudet pojazdów szynowych

[7] PN ISO 14644. Pomieszczenie czyste i zwiazane z nimi środowiska kontrolowane.

[8] BN-71-1131-07. Łożyska toczne. Łożyska walcowe do osi zestawów kołowych pojazdów szynowych.

[9] PN-71/C-04135. Przetwory naftowe. Analiza sitowa. Wytyczne stosowania. Norma wycofana.

[10] .PN-72/C-96134. Przetwory naftowe. Smary plastyczne ŁT ogólnego stosowania do tożysk tocznych. Norma wycofana.

[11] PN-55/C-04020. Przetwory naftowe. Pomiar kroplenia metoda Ubbelohdego. Norma wycofana.

[12] PN-56/C-04093. Przetwory naftowe. Badanie działania korodujacego na metale. Norma wycofana.

[13] PN-59/C-04136. Przetwory naftowe. Badanie stabilności strukturalnej smarów statych. Norma wycofana.

[14] PN-58/C-04142. Przetwory naftowe. Badanie na substancje rysujace $w$ smarach statych. Norma wycofana.

[15] PN-68/C-04152. Przetwory naftowe. Pomiar granicznego naprężenia ścinajacego smarów statych. Norma wycofana.

[16] PN-68/C-04523. Przetwory naftowe. Oznaczanie zawartości wody metoda destylacyjnq. Norma wycofana.

[17] PN-55/C-04141. Przetwory naftowe. Smary state. Norma wycofana.

[18] Publikacja Nr 81115 PIA/86. Smarowanie łożysk tocznych. FAG Kugelfischer Georg Schäfer KgaA.

[19] Publikacja NrWL 82102/2DA/96 Walzlagerschäden. Schadenserkennung und Begutachtung gelaufener Wälzlager. Łożyska walcowe. Rozpoznawanie i ocena zużytych łożysk walcowych. FAG Kugelfischer Georg Schäfer.

[20] ITN-30 wydanie B. Łożyska toczne. Montaż i rewizja okresowa łożysk NJ+NJP dla zestawów kołowych wagonów osobowych i towarowych. Warunki techniczne ITN-30. Wydanie B. Centrala TechnicznoHandlowa Przemystu Precyzyjnego „Prema”. Warszawa 1980.

[21] Katalog WL 41 520/2PLA/97. FAG. Łożyska toczne. Łożyska kulkowe. Łożyska wałeczkowe. Oprawy. Części przynależne. FAG Kugelfischer Georg Schäfer. 